\title{
Total Synthesis of Waltherione F, a Nonrutaceous 3-Methoxy-4- quinolone, Isolated from Waltheria indica L. F.
}

\author{
Abel A. Arroyo Aguilar, Santiago J. Bolívar Avila, Teodoro S. Kaufman, *(i) and Enrique L. Larghi* \\ Instituto de Química Rosario (IQUIR, CONICET-UNR) and Facultad de Ciencias Bioquímicas y Farmacéuticas, Universidad \\ Nacional de Rosario, Suipacha 531, S2002LRK Rosario, Argentina
}

Supporting Information

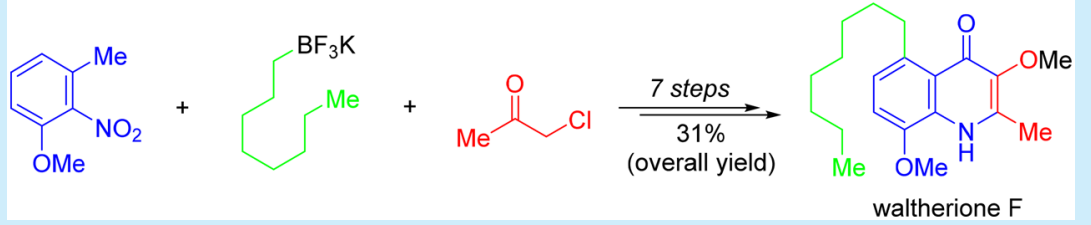

ABSTRACT: Waltherione F was totally synthesized in seven steps and 31\% overall yield from 2-nitro-3-methylanisole without the use of protecting groups. Key steps in the sequence were a Suzuki-Miyaura coupling to attach the $n$-octyl chain and a microwave-promoted cyclization of an acetonyl anthranilate to give the heterocyclic core whose 3-OH was $\mathrm{O}$-methylated.

$\mathrm{N}$ atural products carrying the 3-methoxy-4-quinolone motif were initially found in Rutaceae; however, nonrutaceous related heterocycles have also been found in other plant families, such as the Malvaceae. The first example of such nonrutaceous alkaloids was melochinone, isolated in 1975 from Melochia tomentosa L. ${ }^{1}$

In 2005, Farias Morel et al. obtained the waltheriones A (1) and B (2) from Waltheria douradinha S.-Hill (Malvaceae). Compound 1 (Figure 1), also found in M. odorata L. F. and M.

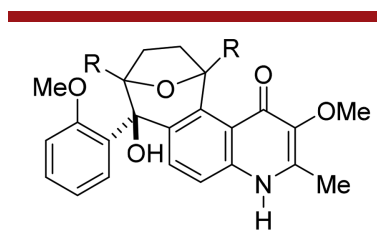

$1 \mathrm{R}=\beta-\mathrm{H}$, waltherione $\mathrm{A}$

$2 \mathrm{R}=\alpha-\mathrm{H}$, waltherione $\mathrm{B}$

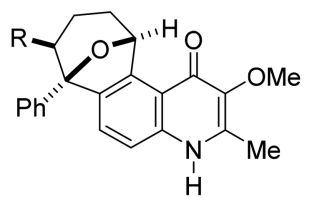

$3 \mathrm{R}=\mathrm{H}$, waltherione $\mathrm{C}$

$4 \mathrm{R}=\mathrm{OH}$, waltherione $\mathrm{D}$

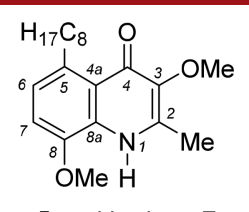

5, waltherione $\mathrm{F}$

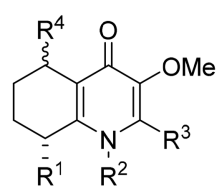

$6 \mathrm{R}^{1}=\mathrm{H}, \mathrm{OH}, \mathrm{OMe},=\mathrm{O}$

$\mathrm{R}^{2}=\mathrm{H}, \mathrm{OMe},=\mathrm{O}$

$\mathrm{R}^{3}=\mathrm{Me}, \mathrm{CH}_{2} \mathrm{OH}$

$\mathrm{R}^{4}=n-\mathrm{C}_{8} \mathrm{H}_{17}$ or $\left(\mathrm{CH}_{2}\right)_{5} \mathrm{Ph}$
Figure 1. Waltherione F (5) and related natural products.

chamaedris St.-Hill, displays a broad spectrum of antifungal activity. $^{2}$ In 2014, the related waltheriones C (3) and D (4) were identified in $M$. odorata. The heterocycle 3 , also found in M. umbellata, ${ }^{3}$ is a cancer chemopreventive agent that inhibits the NF- $\kappa \mathrm{B}$ transcription factor $\left(\mathrm{IC}_{50} \sim 50 \mu \mathrm{M}\right)$ and is cytoprotective against $\mathrm{HIV}$ infection and also active toward Trypanosoma cruzi. ${ }^{4}$
Further, the roots of Waltheria indica L. afforded the waltheriones $\mathrm{E}-\mathrm{L}, 5$ which except for waltherione $\mathrm{F}$ (5) share the structural motif 6, differing in its decoration; they have anti-T. cruzi activity. Additional heterocycles exhibiting this framework, such as the waltheriones $M-Q^{6}$ and others, are included in this small but fast-growing family. ${ }^{7}$ Many of them also exhibit interesting bioactivity. ${ }^{8}$

Taking into account our continuous interest in the synthesis of natural products, ${ }^{9}$ considering the originality of the structures of this family members, and the scarcity of synthetic activity in the field, ${ }^{10}$ we decided to undertake the total synthesis of waltherione $\mathrm{F}(\mathbf{5})$.

In the retrosynthetic analysis of 5 (Scheme 1), the disconnection of the $\mathrm{C} 2-\mathrm{C} 3$ moiety revealed the acetonyl anthranilate 7 as a suitable precursor, which should give the quinolone core through a Friedländer-type cyclization and rearrangement. ${ }^{11}$ Disconnection of the $n$-octyl moiety and the ester group in 7 unveiled the $o$-nitrobenzoic acid derivative 8 as a suitable intermediate, fitted with a proper activating group (AG) to anchor the side chain.

Final retrosynthetic considerations led to 2-methyl-3-nitroanisole (9) as the most suitable starting material, which should be oxidizable to the related acid and also properly functionalized ortho to the carboxyl group. ${ }^{12}$

Our synthetic efforts began with oxidation of the anisole 9 with $\mathrm{KMnO}_{4}$ in $\mathrm{H}_{2} \mathrm{O}$ (Scheme 2); this gave the benzoic acid 10 in $67 \%$ yield. ${ }^{13}$ Taking into account that the proposed strategy heavily relies on a final selective $O$-methylation of a tridentate substrate, and that this is a challenging task, ${ }^{14 a}$ a simple model was first built, implementing an approach analogous to that of Hradil et al. ${ }^{14 b}$

Received: July 16, 2018 
Scheme 1. Retrosynthetic Strategy toward Waltherione F (5)

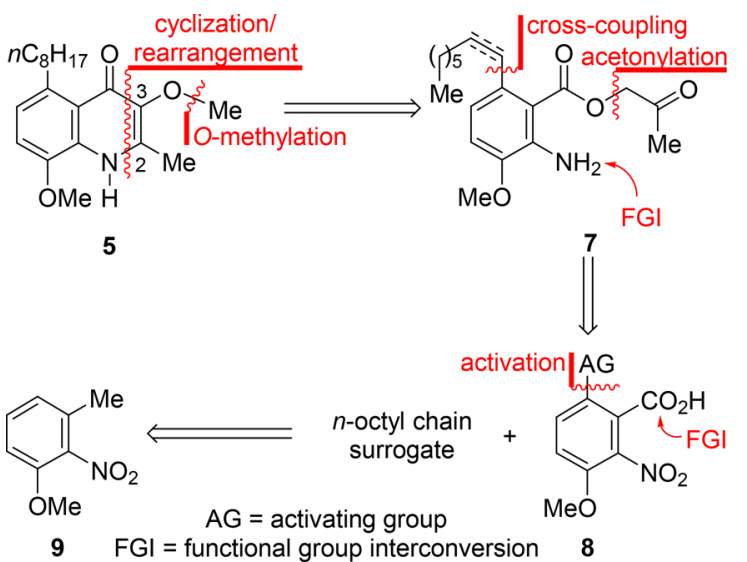

Scheme 2. Synthesis of Model Compound 14

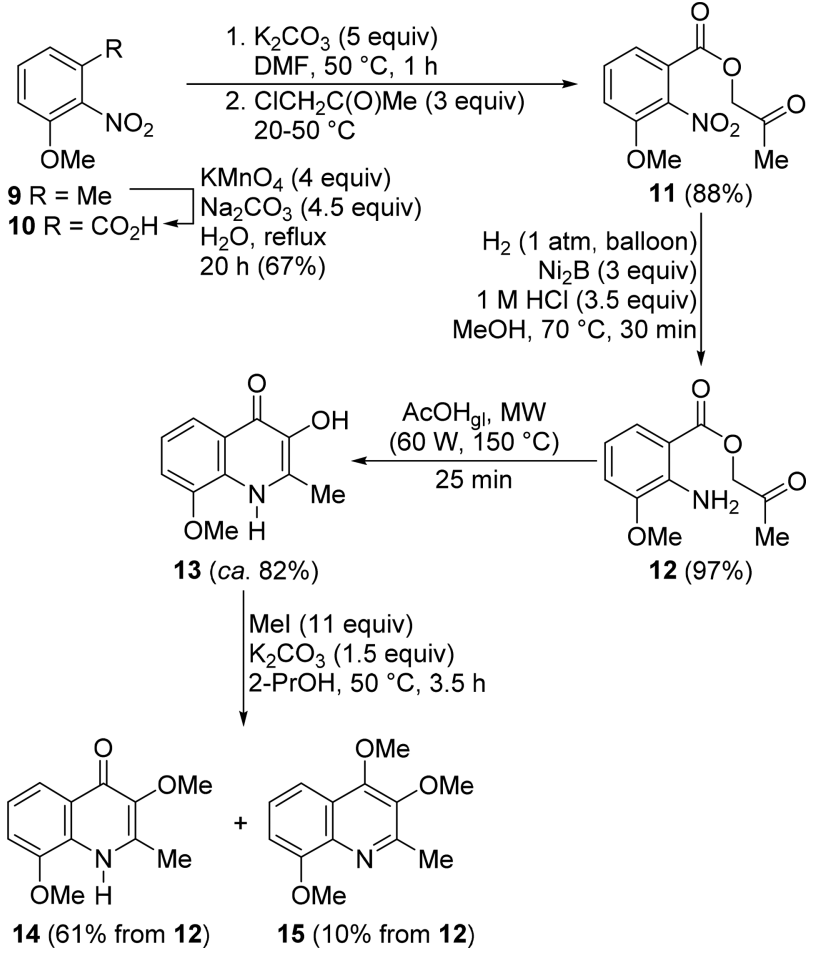

Therefore, the acid $\mathbf{1 0}$ was acetonylated ( $88 \%$ yield) with freshly prepared chloroacetone, ${ }^{15}$ and the nitro group of the resulting ester 11 was subjected to a chemoselective reduction. However, the tested reducing agents $\left(\mathrm{H}_{2}, 10 \% \mathrm{Pd} / \mathrm{C}, \mathrm{Zn}^{0}\right.$ / $\left.\mathrm{NH}_{4} \mathrm{HCO}_{2}, \mathrm{TES} / \mathrm{CHCl}_{3}, \quad \mathrm{SnCl}_{2}, \quad \mathrm{Fe}^{0} / \mathrm{NH}_{4} \mathrm{Cl}\right)^{16}$ afforded complex mixtures of esters and acids containing partial reduction derivatives of the nitro moiety. The anthranilic ester 12 was also detected, albeit in low yield.

An insightful analysis of the literature revealed that nickel boride $\left(\mathrm{Ni}_{2} \mathrm{~B}\right)^{17 \mathrm{a}}$ has been used for the efficient conversion of aromatic nitro groups to the corresponding anilines in the presence of alkenes, halides, and esters. ${ }^{17 \mathrm{~b}}$ Delightfully, the reduction of 11 with 3 equiv of freshly prepared $\mathrm{Ni}_{2} \mathrm{~B}$ gave the anthranilate $\mathbf{1 2}$ in $97 \%$ yield.

Next, the cyclization step was explored, but carrying the reaction in NMP afforded a meager 34\% yield of 13; hence, alternative conditions were sought. ${ }^{18}$ After experimenting with different solvents (TFA, $\mathrm{AcOH}, \mathrm{Ph}_{2} \mathrm{O}$ ) under conventional and microwave heating, it was found that $\mathrm{AcOH}$ was an efficient promoter of the microwave-assisted $\left(60 \mathrm{~W}, 150{ }^{\circ} \mathrm{C}\right)$ cyclization/rearrangement sequence, ${ }^{19}$ which furnished 13 in $80 \%$ yield.

Quinolone 13 bears three different alkylation positions (N, $\mathrm{O}_{3}, \mathrm{O}_{4}$ ), and overalkylated products are possible, depending on the reaction conditions. A literature survey revealed that conditions for 3-OH alkylation in 3-hydroxy-4-quinolones are scarce. Therefore, an optimization needed to be performed, with alcoholic solvents being preferred over polar aprotic media (DMF, MeCN, $\mathrm{Me}_{2} \mathrm{CO}$ ), ${ }^{18}$ and mild bases $\left(\mathrm{K}_{2} \mathrm{CO}_{3}\right.$, $\mathrm{Na}_{2} \mathrm{CO}_{3}, \mathrm{NaHCO}_{3}$ ) needed to be used to ensure selectivity since $\mathrm{NaH}$ and the like promoted dialkylation. ${ }^{20}$

It was found that reaction of 13 with $\mathrm{MeI}$ in $2-\mathrm{PrOH}$ gave a $61 \%$ yield of 14 , accompanied by $10 \%$ of 15 . Efforts to perform the transformation $\mathbf{1 2} \rightarrow \mathbf{1 4}$ as a "two step-one pot" process ${ }^{21}$ did not improve the yields. The methylation position was determined unambiguously by NOE and HMBC experiments. The remainder of the total synthesis of $\mathbf{5}$ was thus undertaken.

Treatment of the acid 10 with $\mathrm{Br}_{2}$ in concentrated $\mathrm{H}_{2} \mathrm{SO}_{4}$, under $\mathrm{Ag}_{2} \mathrm{SO}_{4}$ promotion, ${ }^{22}$ provided 16 in $99 \%$ yield (Scheme 3). Occasionally, the dibrominated derivative 16a was obtained

Scheme 3. Synthesis of the Key Intermediate 19

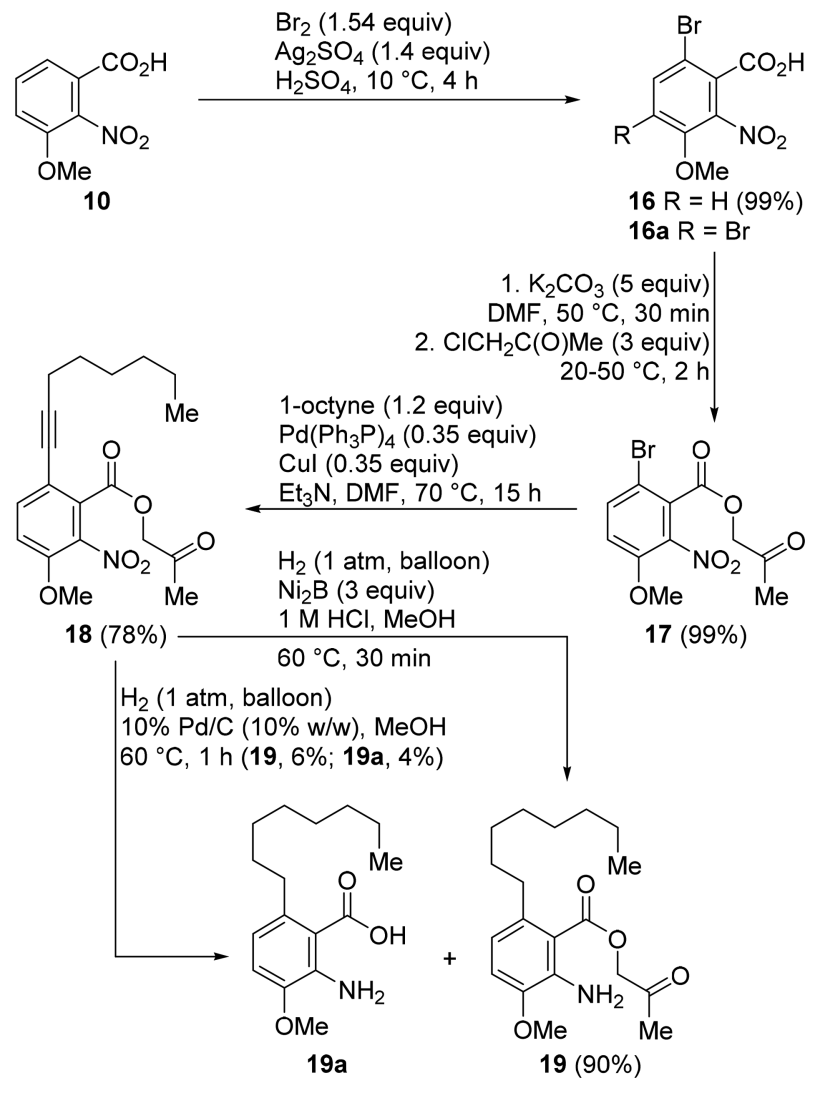

as a byproduct. Following Hradil's strategy, the bromide $\mathbf{1 6}$ was acetonylated with chloroacetone, giving the ester 17 in excellent yield (99\%). Then the introduction of the $n$-octyl group was attempted ${ }^{23 a}$ under conditions compatible with acetonyl esters. ${ }^{23 \mathrm{~b}}$

Due to the commercial availability of 1-octyne, a Sonogashira reaction was initially performed. Thus, the bromoarene 17 was treated with 1-octyne in DMF under 
$\mathrm{Pd}\left(\mathrm{PhP}_{3}\right)_{4}$ and $\mathrm{CuI}$ catalysis (0.35 equiv each), ${ }^{24}$ affording $78 \%$ yield of the coupled product 18 and ca. $4 \%$ of 11 . The alkyne 18 proved to be unstable to the chromatographic purification conditions; therefore, the crude reaction product was carried to the next step of the sequence.

Here, a simultaneous hydrogenation of the alkyne moiety and reduction of the nitro group was envisioned, to provide the corresponding 3-octylaniline derivative. Unfortunately, under Pd catalysis $\left(\mathrm{H}_{2}, 10 \% \mathrm{Pd} / \mathrm{C}, \mathrm{MeOH}\right)$ a complex mixture of products was obtained where 19 was identified in a disappointing yield of $6 \%$, at best.

A small amount of anthranilic acid 19a (4\%) was also isolated and unequivocally identified by conversion to its $O$ acetonyl ester 19 (Scheme 3). Presumably, this byproduct arose from hydrolysis of the acetonyl ester, which occurred after the alkyne hydrogenation and nitro group reduction stages. In light of these results, the strategy toward installation of the n-octyl group was revised.

The cross-coupling of properly activated arenes with alkyltrifluoroborate salts under palladium catalysis ${ }^{25}$ is one of the most powerful emerging methodologies to build $\mathrm{C}_{\mathrm{sp}}{ }^{3}-\mathrm{C}_{\mathrm{sp}}{ }^{2}$ bonds. Hence, potassium $n$-octyltrifluoroborate (20) was synthesized from $n$-octyl bromide ${ }^{26}$ and further cross-coupled with 17 using dppf as ligand. ${ }^{27}$ After the system was stirred overnight at $80{ }^{\circ} \mathrm{C}$, the coupled product 21 was obtained in $81 \%$ yield (Scheme 4 ), accompanied by some of the protodebrominated precursor $\mathbf{1 1}$ and a small amount of the related benzoic acid $\mathbf{1 0}$.

\section{Scheme 4. Synthesis of Waltherione F (5)}

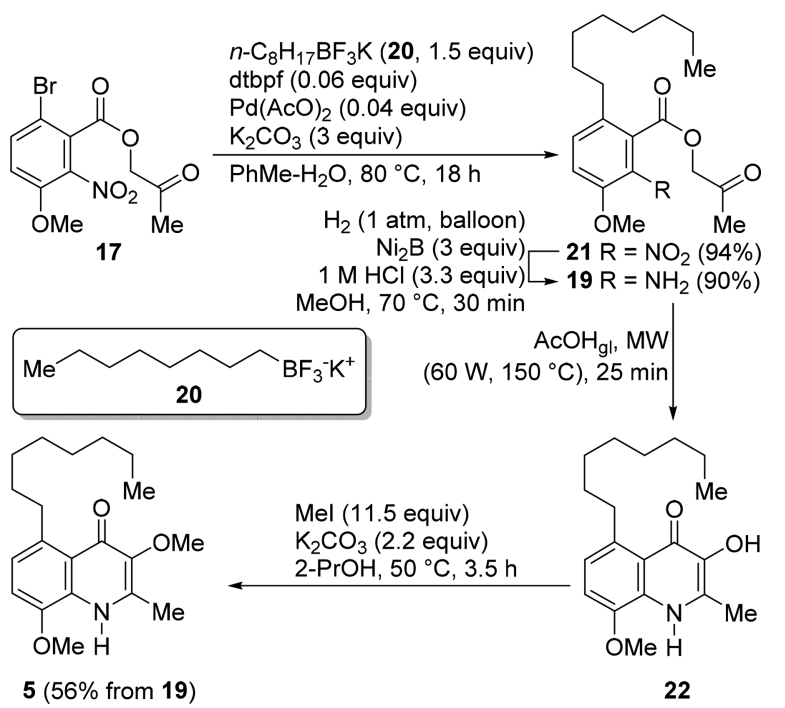

In order to suppress the formation of byproducts, the reaction was performed in the presence of dtbpf since sterically hindered phosphine ligands increase the oxidative insertion pathway. ${ }^{12}$ This ligand change gave access to the desired product 21 in an improved $94 \%$ yield.

With the coupled product $\mathbf{2 1}$ in hand, its reduction was performed with freshly prepared $\mathrm{Ni}_{2} \mathrm{~B}$ (3 equiv) under a $\mathrm{H}_{2}$ atmosphere to give the anthranilate 19 in $90 \%$ yield.

Next, 19 was dissolved in $\mathrm{AcOH}$ and subjected to microwave heating, smoothly cyclizing to 22 after $25 \mathrm{~min}$ at $150{ }^{\circ} \mathrm{C}$. Unexpectedly, the chromatographic purification of 22 on $\mathrm{SiO}_{2}$ proved troublesome; ${ }^{28}$ therefore, the solvent was removed under high vacuum, and the final methylation step was performed on this crude material with $\mathrm{MeI}$ and $\mathrm{K}_{2} \mathrm{CO}_{3}$ in 2-PrOH at $50{ }^{\circ} \mathrm{C}$ during $3.5 \mathrm{~h}$. This furnished synthetic waltherione $\mathrm{F}(5)$ in $56 \%$ overall yield from 19 after silica gel chromatography. The ${ }^{1} \mathrm{H}$ and ${ }^{13} \mathrm{C}$ NMR spectral data of the synthetic compound in $\mathrm{MeOH}-d_{4}$ were in full agreement with those of the natural product. ${ }^{5}$

In conclusion, the first total synthesis of waltherione $\mathrm{F}$ has been accomplished in seven steps and $31 \%$ overall yield from commercial 3-methyl-2-nitroanisole without the use of protecting groups. The sequence involved the preparation of 2-nitro-3-methoxy-6-bromobenzoic acid, the synthesis of its acetonyl ester, and its subsequent Suzuki-Miyaura coupling with potassium $n$-octyltrifluoroborate under palladium catalysis using dtbpf as ligand. A chemoselective nitro group reduction with $\mathrm{Ni}_{2} \mathrm{~B}$, AcOH-promoted cyclization of the resulting acetonyl anthranilate under microwave irradiation, and final 3-OH methylation completed the heterocyclic pseudane core.

\section{ASSOCIATED CONTENT}

\section{S Supporting Information}

The Supporting Information is available free of charge on the ACS Publications website at DOI: 10.1021/acs.orglett.8b02221.

Detailed experimental procedures and characterization data of compounds (PDF)

\section{AUTHOR INFORMATION}

\section{Corresponding Authors}

*E-mail: kaufman@iquir-conicet.gov.ar.

*E-mail: larghi@iquir-conicet.gov.ar.

ORCID

Teodoro S. Kaufman: 0000-0003-3173-2178

Notes

The authors declare no competing financial interest.

\section{ACKNOWLEDGMENTS}

This research was supported by ANPCyT (PICT 2014-0445), CONICET (PIP 2012-0471 and PUE IQUIR 2016), and SECyT-UNR (BIO469). A.A.A.A. and S.J.B.A. acknowledge CONICET for awarding their Doctoral fellowships.

\section{REFERENCES}

(1) (a) Kapadia, G. J.; Paul, B. D.; Silverton, J. V.; Fales, H. M.; Sokoloski, E. A. J. Am. Chem. Soc. 1975, 97, 6814-6819. (b) Kapadia, G. J.; Shukla, Y. N.; Basak, S. P.; Fales, H. M.; Sokoloski, E. A. Phytochemistry 1978, 17, 1444-1445.

(2) (a) Hoelzel, S. C. S. M.; Vieira, E. R.; Giacomelli, S. R.; Dalcol, I. I.; Zanatta, N.; Morel, A. F. Phytochemistry 2005, 66, 1163-1167. (b) Gressler, V.; Stüker, C. Z.; de O. C. Dias, G.; Dalcol, I. I.; Burrow, R. A.; Schmidt, J.; Wessjohann, L.; Morel, A. F. Phytochemistry 2008, 69, 994-999. (c) Dias, G. C. D.; Gressler, V.; Hoenzel, S. C. S. M.; Silva, U. F.; Dalcol, I. I.; Morel, A. F. Phytochemistry 2007, 68, 668672. (d) Emile, A.; Waikedre, J.; Herrenknecht, C.; Fourneau, C.; Gantier, J.-C.; Hnawia, E.; Cabalion, P.; Hocquemiller, R.; Fournet, A. Phytother. Res. 2007, 21, 398-400.

(3) Erwin, E.; Noor, A.; Soekamto, N. H.; van Altena, I.; Syah, Y. M. Biochem. Syst. Ecol. 2014, 55, 358-361.

(4) (a) Jadulco, R. C.; Pond, C. D.; Van Wagoner, R. M.; Koch, M.; Gideon, O. G.; Matainaho, T. K.; Piskaut, P.; Barrows, L. R. J. Nat. Prod. 2014, 77, 183-187. (b) Monteillier, A.; Cretton, S.; Ciclet, O.; Marcourt, L.; Ebrahimi, S. N.; Christen, P.; Cuendet, M. J. Ethnopharmacol. 2017, 203, 214-225. (c) Cretton, S.; Bréant, L.; 
Pourrez, L.; Ambuehl, C.; Perozzo, R.; Marcourt, L.; Kaiser, M.; Cuendet, M.; Christen, P. Fitoterapia 2015, 105, 55-60.

(5) Cretton, S.; Breant, L.; Pourrez, L.; Ambuehl, C.; Marcourt, L.; Ebrahimi, S. N.; Hamburger, M.; Perozzo, R.; Karimou, S.; Kaiser, M.; Cuendet, M.; Christen, P. J. Nat. Prod. 2014, 77, 2304-2311.

(6) Cretton, S.; Dorsaz, S.; Azzollini, A.; Favre-Godal, Q.; Marcourt, L.; Ebrahimi, S. N.; Voinesco, F.; Michellod, E.; Sanglard, D.; Gindro, K.; Wolfender, J.-L.; Cuendet, M.; Christen, P. J. Nat. Prod. 2016, 79, 300-307.

(7) (a) Wang, G. C.; Li, T.; Wei, Y.-R.; Zhang, Y.-B.; Li, Y.-L.; Sze, S. C. W.; Ye, W. C. Fitoterapia 2012, 83, 1643-1647. (b) Buske, A.; Busemann, S.; Mühlbacher, J.; Schmidt, J.; Porzel, A.; Bringmann, G.; Adam, G. Tetrahedron 1999, 55, 1079-1086. (c) Bringmann, G.; Schlauer, J.; Rischer, H.; Wohlfarth, M.; Mühlbacher, J.; Buske, A.; Porzel, A.; Schmidt, J.; Adam, G. Tetrahedron 2000, 56, 3691-3695.

(8) (a) Zongo, F.; Ribuot, C.; Boumendjel, A.; Guissou, I. J. Ethnopharmacol. 2013, 148, 14-26. (b) Jang, J. Y.; Le Dang, Q.; Choi, Y. H.; Choi, G. J.; Jang, K. S.; Cha, B.; Luu, N. H.; Kim, J. C. J. Agric. Food Chem. 2015, 63, 68-74. (c) Jang, J. Y.; Le Dang, Q.; Choi, Y. H.; Choi, G. J.; Jang, K. S.; Cha, B.; Luu, N. H.; Kim, J. C. J. Agric. Food Chem. 2015, 63, 3803-3803. (d) Al Muqarrabun, L. M. R.; Ahmat, N. Eur. J. Med. Chem. 2015, 92, 514-530.

(9) (a) Méndez, M. V.; Heredia, D. A.; Larghi, E. L.; Bracca, A. B. J.; Kaufman, T. S. RSC Adv. 2017, 7, 28298-28307. (b) Pergomet, J. L.; Bracca, A. B. J.; Kaufman, T. S. Org. Biomol. Chem. 2017, 15, 70407049. (c) Pergomet, J. L.; Larghi, E. L.; Kaufman, T. S.; Bracca, A. B. J. RSC Adv. 2017, 7, 5242-5250. (d) Simonetti, S. O.; Larghi, E. L.; Bracca, A. B. J.; Kaufman, T. S. Org. Biomol. Chem. 2012, 10, 41244134.

(10) Mäkinen, M. E.; Mallik, R.; Siitonen, J. H.; Kärki, K.; Pihko, P. M. Synlett 2017, 28, 1209-1213.

(11) (a) Marco-Contelles, J.; Pérez-Mayoral, E.; Samadi, A.; Carreiras, M. C.; Soriano, E. Chem. Rev. 2009, 109, 2652-2671.

(b) Fallah-Mehrjardi, M. Mini-Rev. Org. Chem. 2017, 14, 187-196.

(12) Cleaver, L.; Nimgirawath, S.; Ritchie, E.; Taylor, W. C. Aust. J. Chem. 1976, 29, 2003-2021.

(13) Glossop, S. C. Synthesis 2007, 2007, 981-983.

(14) (a) Morel, A. F.; Larghi, E. L.; Selvero, M. M. Synlett 2005, 2755-2758. (b) Hradil, P.; Hlaváč, J.; Lemr, K. J. Heterocycl. Chem. 1999, 36, 141-144.

(15) Clamens, S.; Teissier, R. Patent FR2633614, 1988.

(16) (a) Hradil, P.; Vaněček, J.; Hlaváč, J.; Ševčík, J. Collect. Czech. Chem. Commun. 1999, 64, 257-264. (b) Gowda, D. C.; Mahesh, B.; Gowda, S. Indian J. Chem. 2001, 40B, 75-77. (c) Mandal, P. K.; McMurray, J. S. J. Org. Chem. 2007, 72, 6599-6601. (d) Chandrappa, S.; Vinaya, K.; Ramakrishnappa, T.; Rangappa, K. S. Synlett 2010, 2010, 3019-3022. (e) Bellamy, F. D.; Ou, K. Tetrahedron Lett. 1984, 25, 839-842. (f) Du, Z.; Hintermann, S.; Hurth, K.; Jacquier, S.; Lehmann, H.; Moebitz, H.; Soldermann, N.; Stojanovic, A. Patent WO010641, 2015.

(17) (a) Khurana, J. M.; Gogia, A. Org. Prep. Proced. Int. 1997, 29, 1-32. (b) Seltzman, H. H.; Berrang, S. D. Tetrahedron Lett. 1993, 34, 3083-3086.

(18) Vaňková, B.; Hlaváč, J.; Soural, M. J. Comb. Chem. 2010, 12, 890-894.

(19) (a) Nishi, T. Chem. Pharm. Bull. 1983, 31, 798-810. (b) Kiyama, R.; Kanda, Y.; Tada, Y.; Fujishita, T.; Kawasuji, T.; Takechi, S.; Fuji, M. Patent WO016275, 2003.

(20) Hodgkinson, J. T.; Gross, J.; Baker, Y. R.; Spring, D. R.; Welch, M. Chem. Sci. 2016, 7, 2553-2562.

(21) Hodgkinson, J. T.; Galloway, W. R. J. D.; Welch, M.; Spring, D. R. Nat. Protoc. 2012, 7, 1184-1192.

(22) Manthey, M. K.; Pyne, S. G.; Truscott, R. J. W. J. Org. Chem. 1990, 55, 4581-4585.

(23) (a) Chinchilla, R.; Nàjera, C. Chem. Rev. 2014, 114, 17831826. (b) Jana, R.; Pathak, T. P.; Sigman, M. S. Chem. Rev. 2011, 111, 1417-1492.

(24) Wei, W.-G.; Zhang, Y.-X.; Yao, Z.-J. Tetrahedron 2005, 61, 11882-11886.
(25) Molander, G. A. J. Org. Chem. 2015, 80, 7837-7848.

(26) Reichle, M. A.; Breit, B. Angew. Chem., Int. Ed. 2012, 51, 57305734.

(27) Molander, G. A.; Figueroa, R. Org. Lett. 2006, 8, 75-78.

(28) Maurer, C. K.; Steinbach, A.; Hartmann, R. W. J. Pharm. Biomed. Anal. 2013, 86, 127-134. 